\title{
Kalang Di Dalam Prasasti-Prasasti Mataram Kuna, Abad VIII-X M : Identifikasi Nilai Budaya Masyarakat Jawa
}

\section{Richadiana Kartakusuma}

Keywords: inscription, ethnoarchaeology, ethnohistory, history, tradition

\section{How to Cite:}

Kartakusuma, R. (2000). Kalang Di Dalam Prasasti-Prasasti Mataram Kuna, Abad VIII-X M : Identifikasi Nilai Budaya Masyarakat Jawa. Berkala Arkeologi, 20(1), 163192. https://doi.org/10.30883/jba.v20i1.815

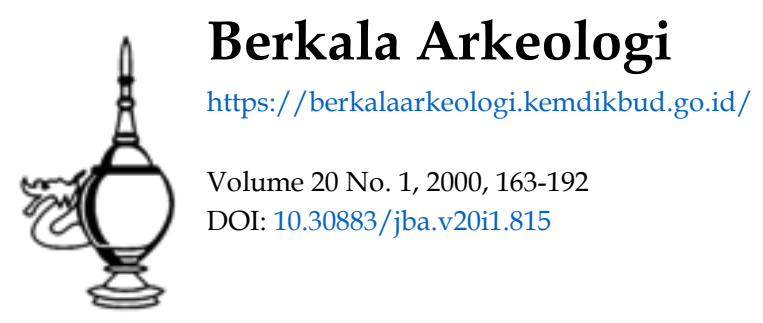

\section{c) (7)(2)}

This work is licensed under a Creative Commons Attribution-NonCommercial-ShareAlike $\underline{4.0 \text { International License. }}$ 


\title{
KALANG DI DALAM PRASASTI-PRASASTI MATARAM KUNA, ABAD VIII-X M : IDENTIFIKASI NILAI BUDAYA MASYARAKAT JAWA
}

\author{
Richadiana Kartakusuma \\ (Pusat Arkeologi)
}

\section{Latar}

Kalang dengan kehidupannya telah banyak ditulis para ahli antara lain oleh Althona (1923); Boechari (1985); Sulardjo Pontjosutirto (1988); M.M. Soekarto Kartoatmodjo (1986); T.M. Hari Lelono (1989); Bambang Sulistyanto (1994), dan yang terakhir adalah Claude Guillot (1999). Tulisan para sarjana itu sesuai dengan minat kajiannya khususnya menyoroti kebiasaan-kebiasaan kalang dengan kehidupannya sebagai kelompok masyarakat (Jawa).

Pontjosutirto (1988) dan Lelono (1989) menyebutkan mereka hidup berkelompok di Yogyakarta dan sekitarnya (Gendeng, Wukirsari-Imogiri, Godean, Tugu, Tegalgendu, Kotagede); di Jawa Tengah (Bantul, Sleman, Petanahan, Ambal-Kebumen, Pekalongan, Semarang, Solo, Sragen); di Jawa Timur (Pegunungan Kendeng: Walikukun, Madiun, Tulungagung, Gresik, Bojonegoro, Surabaya dan Banyuwangi). Berdasarkan tulisan Boechari, Kartoatmodjo dan Guillot diketahui bahwa diantara kebiasaan-kebiasan kalang yang paling menonjol adalah kegiatan pertukangan terutama mengolah kayu atau pengrajin kayu. Dapat dimengerti jikalau Guillot menegaskan bahwa kalang sebagi minoritas etnis itu lebih cenderung disebut sebagai golongan profesional yang ahli membuat barang-barang tertentu ataupun bidang pekerjaan tertentu.

Pendapat itu sejalan dengan informasi Nurhadi (pers. Comm) bahwa individu/kelompok kalang tidak melulu menekuni kayu sebagai bagian kehliannya tetapi juga mengolah bahan-bahan lainnya seperti logam (gamelan, senjata, keris) kulit (wayang) dan batu (jlagra). Hasil karyanya sangat baik dan itu pula yang telah menghantarnya ke tingkat kehidupan yang lebih bahkan mampu menembus lingkungan istana (pada masa Sultan Agung). Di antara mereka ada yang bekerja di kraton Yogyakarta sebagai abdi dalem gowongan (bhs. Jawa: gowong = pohon, kayu) dan di kraton Solo sebagai abdi dalem narawreksa. Oleh kalangan kraton Solo kelompok kalang dipercaya mengelola hutan krendhowahono (gunung Lawu) dan mereka pula yang turut merenovasi kraton Solo setelah hangus terbakar. Keahlian dan jasa-jasanya dihargai pihak kraton sehingga di antaranya dan yang dianugrahi (gelar) tituler. 
Kalangan masyarakat Jawa percaya (Nurhadi: pers. comm; Lelono 1989) bahwa orang (wong) kalang memiliki ekor, hidup di lingkungan hutan dan bermatapencaharian sebagai tukang (menebang kayu). Kaitannya dengan hutan inilah, asal-usul kalang dianggap ada hubungannya dengan hewan tertentu seperti babi dan anjing. Karenya mereka memiliki adat kebiasaan agak berbeda yang telah berlangsung semenjak nenekmoyangnya. Adat kebiasaan dan tradisi yang secara dinamis berfungsi sebagai alat atau mekanisme pengawasan dalam menyesuaikan diri dengan perubahan situasi, kondisi dan menjadi ciri yang membedakannya dengan kelompok masyarakat Jawa di lingkungannya.

Ciri-ciri praislam yang terutama dikenali adalah tradisi upacara obong (membakar mayat), memperingati seribu hari wafatnya seseorang (leluhur) dilambangkan dengan arca bunga atau puspasarira; mengharuskan perkawinan silang antara saudara sepupu; memupuk wiraswasta sejak dini dengan diberi modal finansiil yang sifatnya mengikat. Artinya jikalau gagal berusaha untuk yang ketiga kalinya maka selanjutnya akan diabaikan. Betapapun aturan yang cenderung mengikat tersebut telah memacu mereka selalu gigih dan pantang menyerah. Di mana mereka hidup dan tinggal hampir selalu berkelompok pada lokasi-loksi tertentu dan oleh kalangan masyarakat Jawa tempat-tempat itu disebut Pakalangan. Di tempat itu kalang dengan keahliannya mengolah sumberdaya alam menjadi benda-benda kebutuhan schari-hari maupun keperluan bagi kepentingan-kepentingan yang lebih khusus antara lain keagamaan (van Mook 1926).

Menarik bahwa selain di dalam kehidupannya sekarang, kalang juga disebutkan dalam prasasti-prasasti khususnya yang bertema sima dari periode Mataram Kuna. Mengingat jumlahnya yang sangat banyak maka dari seluruh prasasti (bertema sima) yang diamati dibatasi hanya dari abad VIII-X Masehi saja. Kalang dalam prasasti tiada dijelaskan detail tetapi disebutkan sebagai individu-individu dengan peranperan, maupun dalam kaitan dengan sejumlah jabatan tertentu. Mengenai kalang diperoleh dalam hubungannya dengan konteks kalimat dan pesan yang diacunya (prasasti). Ada kecenderungan bahwa kalang banyak memegang peranan, kalau tidak dikatakan "yang terbanyak" di lingkungan desa dan wilayah yang lebih luas. Yang dapat dicatat adalah kalang sebagi tuhan, juru, pande (kalang), tunggudurung, mangwwu, makmit sima (kamulan) atau kalang saja; yang didahului sang da (?), rakarayan dengan tambahan keterangan watubungkal, ron (Damais 1970). Betapapun peran-perannya yang menonjol adalah jabatannya sebagai rama tpi siring pinaka saksi ning manusuk sima (= pejabat desa tetangga terdekat, langsung berbatasan diundang sebagai saksi pengukuhan sima).

Kalang dan identifikasinya terhadap nilai budaya masyarakat Jawa merujuk kepada makna kalang sebagai individu/kelompok masyarakat itu adalah kehidupannya yang 
dianggap unik; keahliannya sebagai tukang (pengrajin), hidup berkelompok di dalam komunitas-komunitas tertentu dan cenderung dekat atau berada di lingkungan yang mengandung sumberdaya alam (hutan). Ada pendapat bahwa istilah ataupun kategori tukang dalam prasasti tergabung ke dalam kelompok undhagi --ahli/keahlian-menyangkut kepandaian-kepandaian atau ketrampilan-ketrampilan tertentu ke dalam pengertian segolongan orang yang trampil melakukan jenis keahlian seperti membuat rumah (kayu, batu) membuat gerabah, membuat benda-benda logam, perhiasan dan lainnya (Pigeaud of., Wolters 1938; cf.Kartoatmodjo 1985).

Sejauh itu ketegasan bahwa kalang merupakan salah satu profesi atau keahlian dari kelompok undhagi belum jelas benar, meskipun di dalam prasasti tercantum juga pande kalang di samping pande lainnya (seperti pande mas, pande tamra, pande gangsa, pande singya-singyan). Ada kecenderungan bahwa kalang sebagai individu/ kelompok keahlian (tukang) itu agak berbeda dengan kelompok undhagi, baik dari istilah jabatan atau jenis perannya di dalam struktur birokratis masyarakat Jawa kala itu.

Boechari menegaskan kalang erat hubungannya dengan pertukangan kayu dan hutan seperti dinyatakan prasasti yakni kalangwungkal, kalangwatu, kalangron atau pandekalang. Keahlian mengolah sumberdaya alam (hutan) menghantar terhadap kemungkinan kalang berada atau dekat dengan lingkungan hutan ataukah hal itu menunjukkan bahwa desa-desa di masa lampau sebagian terbesar masih berupa hutan sehingga kemungkinan bergaul dan mengolah sumberdaya di dalamnya. Begitu pula tradisi yang diasumsikan sebagai sisa-sisa kepercayaan praislam itu mencerminkan masyarakat Jawa dengan sisi kehidupan yang agak berbeda merujuki kepada kondisi dan situasi masyarakat Jawa masa lampau sebagai yang disebutkan dalam sejumlah prasasti? Upaya mengetahuinya dilakukan dengan menempatkan kalang kepada tatarannya sesaui kapasitas informasi yang diacunya. Kiranya kalang dapat dimengerti sejalan nilai budayanya kala itu yang pada gilirannnya dapat mengisi celah-celah kosong tentang keberadaan kalang di masa lampau dengan masa kini. 
NALANG: PRASASTI-PRASASTI DARI MASA MATARAM KUNA JAWA TENGAH

\begin{tabular}{|c|c|c|c|}
\hline Prasasti & Tahun & Keterangan (Kalimat Prasasti & Keterangan (Terjemahan) \\
\hline $\begin{array}{l}\text { I Kamalagi }(\mathrm{a}: 16-17) \\
\qquad(18-20)\end{array}$ & 743 Saka & $\begin{array}{l}\text {--ri gununnan si manhem rama ni manajan } \\
\text {--ri karyyanan si sumdek rama ni kunuh } \\
\text { ri san mapatih ri sukun si wanun ... }\end{array}$ & $\begin{array}{l}=\text { kalang di pegunungan bemama si Mannhem } \\
=\text { kalang pada (ra) karyan (nan) Mapatih bemama si } \\
\text { Sumdek } \\
\text { Sumdek; (kalang) desa Sukun bernama si Wangun }\end{array}$ \\
\hline $\begin{array}{l}2 \text { Tulangair (a: } 10-11) \\
\qquad(36-37) \\
(36-37)\end{array}$ & 772 Saka & $\begin{array}{l}\text { Wadwa rakarayan mapatih milu san da-- } \\
\text { Isirikan san garawuy I ( } t i) \text { run san } \\
\text { talaga } \\
\text { juru in sulan kunin si buntal }\end{array}$ & $\begin{array}{l}=\text { kalang sebagai pejabat keagamaan, pada rakarayan } \\
\text { Mapa- } \\
\text { tit Sirikan bemm Garawuy; pada (watak) Tiruan bernama } \\
\text { sang Talaga } \\
=\text { kalang sebagai juru di Sulangkuning bernama si Bantal }\end{array}$ \\
\hline 3 Siwagrha (a:35-36) & 778 Saka & Kita ta--anakbanua gusti wagus tinajar & $=$ kalang sebagai (kelompok) warga desa \\
\hline 4 Wukiran $(a: 12 \cdot 13)$ & 784 Saka & $\begin{array}{l}\text { Iwan san pamgat mahhakan ikanan sawah } \\
\text { san tuha--pu nista }\end{array}$ & $\begin{array}{l}\text { = tuha kalang bernama pu Nista, pengurus sawah sang } \\
\text { sang Pamgat }\end{array}$ \\
\hline 5 Tunahan $(\mathrm{lb}: 5-6)$ & 794 Saka & rama anum maturus -. si kais .... & $\begin{array}{l}\text { = kalang bernama si Kais, sesepuh yang turut mengerjakan } \\
\text { batas (sima) }\end{array}$ \\
\hline 6 Sri Manggala II & 746 Saka & saksi ramanta I salinsinan patih -. & $=$ kalang (sesepuh) di Salingsingan sebagai saksi \\
\hline $\begin{array}{l}7 \text { Humanding }(\mathrm{lb}: 1) \\
\qquad(2: 2-3)\end{array}$ & 797 Saka & $\begin{array}{l}\text { I/ managam kon I humandin--si rawa ... } \\
\text { anakbi ni managam kon--si andalan... } \\
\text { wanua I tpi sirin ... I palatanan--si wuru }\end{array}$ & $\begin{array}{l}\text { = kalang pemimpin desa Humanding bernam si Rawa } \\
\text { (dan)... } \\
\text { istrinya bemama si Andalan } \\
=\text { kalang bemama si Rawa penduduk daerah perbatasan } \\
\text { (di) } \\
\text { desa Palatangan }\end{array}$ \\
\hline 8 Jurungan $(26.6)$ & 798 Saka & $\begin{array}{l}\text { // anakwanua l jurunan ... .- si dana } \\
\text { rama ni ram ... anakbinya... }\end{array}$ & $\begin{array}{l}\text { = kalang sebagai penduduk desa jurungan bernama si Dana } \\
\text { ayahnya iram ... (dan) istrinya... }\end{array}$ \\
\hline 9 Haliwangbang $(1 b: 9)$ & 799 Saka & -- si pundanil rama ni kais...--si wala... & $\begin{array}{l}\text { = kalang bernama si Pundangil ayahnya Kais... (kalang) } \\
\text { bernama si Wala... }\end{array}$ \\
\hline$(2 a: 6-7)$ & & $\begin{array}{l}\text { // wanua I tpi sirin } 4 \text { I hanunnan -- si } \\
\text { julum I limup winkas... I sranan -si } \\
\text { dipa pikatan gusti... kapua ya winaih }\end{array}$ & $\begin{array}{l}\text { = kalang sebagai dari daerah perbatasan: di Hanungnang } \\
\text { bernama si julung ...di Srangau bersama si Dipa..diberi } \\
\text { beri persembahan... }\end{array}$ \\
\hline
\end{tabular}




\begin{tabular}{|c|c|c|c|}
\hline$(26: 4-5)$ & & $\begin{array}{l}\text { anakbi nin managam kon -- si wadai -si } \\
\text { gereme...kalanron si domok... }\end{array}$ & $\begin{array}{l}=\text { kalang sebagai istri pemimpin desa bemama si wadai, } \\
\text { si Gereme... (dan) kalang ron bernama si Domok }\end{array}$ \\
\hline$(26: 10-3 a: 1)$ & & $\begin{array}{l}\text { // I haliwanban...//kalima...-- si glar } \\
\text { si balun kapua winaih... }\end{array}$ & $\begin{array}{l}=\text { kalang dari esa Haliwangbang bernama si Glar (dan) si } \\
\text { Balun, semua diberi (persembahan)... }\end{array}$ \\
\hline$(3 a: 8-9)$ & & $\begin{array}{l}\text { // wanua I tpi sirin } 4 \text { I gunun tencyan-- } \\
\text { si rulih I mungut --si sukra in barabay... } \\
\text { talaga I limpar -- si karnna kapua ya ... } \\
\text { anakbi nin managam kon--si udi si wisik }\end{array}$ & $\begin{array}{l}\text { = kalang dari daerah-daerah perbatasan: si Rulih di gunung } \\
\text { tanayan, si Sukra di Munggu, di Limpar si Karnna diberi } \\
\text { (persembahan...) } \\
=\text { kalang bernama si Udi, di Wisik istri pemimpin desa }\end{array}$ \\
\hline $\begin{array}{l}10 \text { Mulak (2a:5-3a:1) } \\
\text { (I) }(3 a: 4-5) \\
(3 a: 5-4)\end{array}$ & 800 Saka & $\begin{array}{l}\text { anun rama managam kon I mulak...--si } \\
\text { - si manawit ramani manhulin ... } \\
\text { manuwu in sima -- } 3 \text { si tungu ramani } \\
\text { gandha si sadenya ramani ghata si gusai } \\
\text { ramani suddhi... } \\
\text { spi sirin kinannan pasek-pasek in tungayun } \\
\text { tuha kalan si tungo ramani gandha I } \\
\text { malih- } \\
\text { yan -- san wadur ramani tni in tis -- si } \\
\text { wanun ramani pandawa... }\end{array}$ & $\begin{array}{l}\text { = para rama di desa Mulak...kalang bernama si Mangawit } \\
\text { ayahnya Manghuling... } \\
\text { = kalang sebagai manguwu daerah sima (3) bernama si } \\
\text { Tunggu ayahnya si Gandha, si Sadenya ayahnya Gatha, } \\
\text { si Gusai ayahnya Suddhi... } \\
\text { = daerah perbatasan diberi persembahan:ketua kalang dari } \\
\text { Tunggayung bernama si Tunggo ayahnya Gandha } \\
\text { di Malihyang bernama sang Wadur ayahnya Tni, di Tis } \\
\text { bernama si Wangun ayahnya Pandawa... }\end{array}$ \\
\hline 11 Mamali (1a:5-6) & 800 Saka & $\begin{array}{l}\text { ikanan rama I namali makabaihan -- si } \\
\text { pundanin ramani kais -- si gatha ramani } \\
\text { danul ... }\end{array}$ & $\begin{array}{l}\text { rama di mamali semuanya: kalang bernama si Pundanin } \\
\text { ayahnya Kais, kalang bernama si Gatha ayahnya Dangul... }\end{array}$ \\
\hline 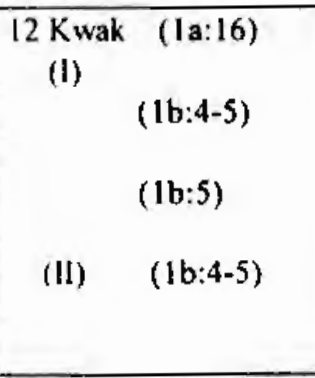 & 801 Saka & $\begin{array}{l}\text { anun rama magman I kwak rikang kala--2 } \\
\text { si pulu ramani sukam si hanin rama pawi } \\
\text { rama ni tpi siring rikan kala -- si waharu } \\
\text { warju rama ni tahun ... } \\
\text { rama tpi sirin ... I halan manuk -- si } \\
\text { sila ramani guday I tigawani-- si wadwa } \\
\text { managam kon I kwak -- } 2 \text { si pulu rama ni } \\
\text { sukam si hidan rama ni pavi ... }\end{array}$ & $\begin{array}{l}\text { = rama desa kwak kala itu kalang, yaitu si Pulu ayahnya } \\
\text { Sukam, si Haning ayahnya Pawi ... } \\
\text { = rama dari perbatasan kala itu: kalang desa waharu ber- } \\
\text { nama si Warju ayahnya Tahun ... } \\
=\text { rama dari perbatasan: kalang desa Halangmanuk } \\
\text { bernama } \\
\text { si Sila ayahnya Guday, dari Tigawangi bernama si Wadwa } \\
=\text { pemimpin desa kwak, kalang ( } 2 \text { orang) bemama si Pulu } \\
\text { ayahnya Pawi }\end{array}$ \\
\hline 13 Salimar (II) & 802 Saka & $\begin{array}{l}\text { ikanan imah ramanta I paktuwani }-. \text { si } \\
\text { teman ... }\end{array}$ & $\begin{array}{l}\text { = dari imah ramanta di Pakuwangi adalah kalang bernama } \\
\text { si Teman }\end{array}$ \\
\hline
\end{tabular}




\begin{tabular}{|c|c|c|c|}
\hline (III) & & \begin{tabular}{|l|}
$\begin{array}{l}\text { nikanan imah ramanta I kandan } \ldots \text { si wama } \\
\text { (si) naisi ... }\end{array}$ \\
\end{tabular} & $\begin{array}{l}\text { = dari imah ramanta di Kandang adalah kalang bernama si } \\
\text { wama (dan) si Ngaisi ... }\end{array}$ \\
\hline 14 Wuantantija (2a:6) & 802 Saka & $\begin{array}{l}\text { ri wamua kabeh naran nika rama ... } \\
\text { kupu si amwir ramani raghu... }\end{array}$ & $\begin{array}{l}\text { = semua rama di desa (salah satunya) di Kupu bernama si } \\
\text { Amwir ayahnya Raghu... }\end{array}$ \\
\hline $\begin{aligned} 5 \text { Taragal } & (\mathrm{lb}: 4) \\
& (\mathrm{lb}: 7-8)\end{aligned}$ & 802 Saka & $\begin{array}{l}\text { // managam kon winaih wdihan ... -- si } \\
\text { dras... } \\
\text { anakbi ni managam kon -. } \\
\end{array}$ & $\begin{array}{l}\text { = pemimpin desa yang diberi kain (bebsod, adalah) kalang } \\
\text { bernama si Gras... } \\
=\text { istri pemimpin desa ... }\end{array}$ \\
\hline $\begin{array}{l}\text { 16 Ratawun (1a:12-13) } \\
\text { (I) } \quad(1 \mathrm{a}: 13)\end{array}$ & 803 Saka & $\begin{array}{l}\text { tpi sirin anu milu irikan susukan sima } \\
\text { pu magya ... } \\
\text { tpi sirin ... I juruk -- pu capah rama ni } \\
\text { rangal ..tpi sirin... I malandan....- pu } \\
\text { dalih ramani rimwit... } \\
\text { tpi sirin ... I kasugihan -- pu teneran } \\
\text { ramani wadwa ... }\end{array}$ & $\begin{array}{l}\text { = (dari) daerah perbatasan hadir dalam peresmian sima } \\
\text { bernama puMagya ... } \\
\text { = daerah perbatasan di jruk kalang bernama pu Capah } \\
\text { ayahnya Ranggal, dari daerah perbatasan di Malandang } \\
\text { kalang bernama pu Dalih ayalnya Rimwit... } \\
\text { = (dari) daerah perbatasan di Kasugihan, kalang bernama } \\
\text { pu Tengerang ayahnya Wadwa ... }\end{array}$ \\
\hline $\begin{array}{rr}7 \text { Ramwi } & (\mathrm{Ib}: 7) \\
& (\mathrm{I} b: 10) \\
\end{array}$ & 804 Saka & $\begin{array}{l}\text { tuhannin -- si turunnan ... } \\
- \text { - I prasada si candra I wineh. }\end{array}$ & $\begin{array}{l}=\text { tuhannya adalah kalang } \\
=\text { kalang dari dacrah Pras }\end{array}$ \\
\hline 18 Kurungan (1a:5) & & anun rama rikan kala .... . pup & $=$ rama kaia itu ... kalang \\
\hline 19 Kaduluran (1a:9-10 & 807 Saka & $\begin{array}{l}- \text { - rikan kala si ratna mwa } \\
\text { winikara punta bhamu mw }\end{array}$ & $\begin{array}{l}\text { si ratna dan pu Misem istrinya } \\
\text { ayi ... }\end{array}$ \\
\hline 20Mungguartan(1a:6-7) & 808 Saka & $\begin{array}{l}\text { fatra saksi ... I munguantan pu kindon -- } \\
\text { pu sistri ... }\end{array}$ & $\begin{array}{l}=\text { saksi mata } \ldots \text { di Mungguantan adalah pu Kindong, } \\
\text { kalang pu Sristi ... }\end{array}$ \\
\hline 21 Rongkap (1b: & 823 Saka & $\begin{array}{l}\text { rama magaman irikanan kala -- si mangal } \\
\text { muang si kya... }\end{array}$ & $\begin{array}{l}\text { = rama desa kala itu adalah kalang bemama si Manggal } \\
\text { dan si Kya ... }\end{array}$ \\
\hline $\begin{array}{l}\text { 22Panggumulan (2a:12) } \\
\text { (I) }\end{array}$ & 824 Saka & $\begin{array}{l}\text { rama magaman irikanan wanua sinusuk I } \\
\text { pangumulan prana } 6 \text {-- manıwu si pinul } \\
\text { ramani uda ... }\end{array}$ & $\begin{array}{l}\text { = para pemimpin di desa Panggumulan yang dijadikan } \\
\text { sima jumlahnya } 6 \text { orang...kalang manguwu bermama si } \\
\text { Pingul ayahnya Uda ... }\end{array}$ \\
\hline $\begin{array}{l}(2 \mathrm{a}: 14) \\
(3 \mathrm{a}: 4-5) \\
(3 \mathrm{a}: 5-6)\end{array}$ & & $\begin{array}{l}\text { minwah magaman prana } 7 \text {.. tungu durun si } \\
\text { si tude ramani bhaisakha ... } \\
\text { rama I sirinan tumut saksi I suru watak } \\
\text { hino--nya si pagar kaki mahu ... } \\
\text { rama I sirinan tumut saksi... I purud } \\
\text { watak parantunan pande--si taji ramani }\end{array}$ & $\begin{array}{l}\text { = dengan pemimpin desa (lainnya)berjumlah } 7 \text { orang } \\
\text { si Tude ayahnya Bhaisaka ... } \\
\text { = rama dari perbatasan yang menjadi saksi,kalang bernama } \\
\text { di Pagar kakeknya Mahu dari desa Suru, wilayah Hino... } \\
\text { = rama dari perbalasan yang menjadi saksi. pande kalang } \\
\text { bernama si Taji ayahnya Swami dari desa Purud,wilayah- }\end{array}$ \\
\hline
\end{tabular}




\begin{tabular}{|c|c|c|c|}
\hline$(3 a: 6)$ & & $\begin{array}{l}\text { swami ... } \\
\text { rama I sirinan tumut saksi... I pastamwi } \\
- \text { - si gumakura rammi jaluk.... }\end{array}$ & $\begin{array}{l}\text { nya Parantungan ... } \\
=\text { rama dari perbatasan yang menjadi saksi... di Pastwamir } \\
\text { kulumg bernama (iuntikira aydaimya Jaluk ... }\end{array}$ \\
\hline 23 Telang (1a:12) & 825 Saka & $\begin{array}{l}\text {.- rika wanua I kalimwaya pirak -- I poh } \\
\text { mas ... - I wakan si wu (...) }\end{array}$ & $\begin{array}{l}\text { = kalang dari desa Kalimwaya ... kalang dari desa Poh } \\
\text { kalang dari desa Wakung bernama si }\end{array}$ \\
\hline $\begin{array}{l}(1 \mathrm{~b}: 1) \\
(1 \mathrm{~b}: 3) \\
(2 \mathrm{~b}: 5-6)\end{array}$ & 827 Saka & $\begin{array}{l}\text {...ri tlan...si wgil ramani gadil... } \\
\text {...muan -- nya sima sanhyan caitya ... } \\
\text { rama tpi sirin milu saksi rin manusuk } \\
\text { sima--si brita ramani taram anakwanua in } \\
\text { pulai watak galan ... }\end{array}$ & $\begin{array}{l}=\ldots \text { di Tlang...bernama si Wgil ayahnya Gadit... } \\
=\ldots \text { dengan kalangnya dari sima bagi sanghyang caitya } \\
=\text { rama dari perbatasan yang menjadi saksi pengukuhan } \\
\text { sima kalang bernama si Brita ayahnya Taram penduduk } \\
\text { desa Pulai termasuk wilayah Galang ... }\end{array}$ \\
\hline $\begin{array}{l}25 \text { Kikilbatu (1b:9) } \\
\text { (1) } \\
\text { (II) } \\
\quad(2 \mathrm{a}: 9) \\
\\
\quad(1 \mathrm{~b}: 10)\end{array}$ & 827 Saka & $\begin{array}{l}\text { patih I kikilwatu irikanan kala pu katan } \\
\text { pu uwan ... } \\
\text { patih rikan kala pu katan ramani dowa-- } \\
\text { pu guban... } \\
\text { - I kakaran pu tguh winkas pu eka ... }\end{array}$ & $\begin{array}{l}\text { = patih di desa Kikilwatu kala itu bernama pu Katang } \\
\text { kalang bernama pu Uwang ... } \\
\text { = patih kala itu bernama pu Katang ayahnya Dawa, kalang } \\
\text { bernama pu Gubang... } \\
=\text { kalang dari desa Kakaran bernama pu } T_{\text {guh }} . . .\end{array}$ \\
\hline 26 Mantyasih(2a:9-10) & 829 Saka & $\begin{array}{l}\text { ikain patih wahuta nayaka lampuran muan } \\
\text { ramani tpi sirin --... }\end{array}$ & $\begin{array}{l}\text { = di sana patih, wahuta, nayaka, lampuran dan rama dari } \\
\text { perbatasan (yaitu) kalang ... }\end{array}$ \\
\hline 27 Wukajana(xa:5) & 830 Saka & $\begin{array}{l}\text { rama tpi sirin... I mahariman -- si knoh } \\
\text { ramani santel ... }\end{array}$ & $\begin{array}{l}\text { = rama dari perbatasan ....di Mahariman kalang bernama si } \\
\text { Knoh ayahnya Sanel ... }\end{array}$ \\
\hline 28 ajigunung(b:14-15) & 832 Saka & $\begin{array}{l}\text {...munvah perttaya wayankappi san hijo } \\
\text { muwah -- I hulu wanua pu bhumi muwah } \\
\text { pu tole ... anak banua I bankal ... } \\
\text { - I rundunan pu lima I wuattanni mas ... } \\
\text { pu sagu ... } \\
- \text { - I seser pu dhara binkas I seser ... }\end{array}$ & $\begin{array}{l}\text { = ... yang merangkap (sebagai) perttaya adalah sang Hijo } \\
\text { dan kalang dari Hulu desa bernama pu Bhumi dan pu Tole } \\
\text { warga desa Bangkal ... } \\
\text { = kalang dari Rundungan bernama pu Lima, dari Wuattan } \\
\text { Mas bermama pu Sagu ... } \\
\text { kalang dari Seser bernama pu Dhara ... }\end{array}$ \\
\hline \begin{tabular}{|l}
29 Lintakan $(2 \mathrm{a}: 7-8)$ \\
\\
$\begin{aligned}(2 \mathrm{a}: 10-11) \\
(2 \mathrm{a}: 14) \\
(2 \mathrm{a}: 15) \\
\\
(2 \mathrm{a}: 18-19)\end{aligned}$ \\
\end{tabular} & 841 Saka & $\begin{array}{l}\text { rama magman I kasugihan -- si balawai } \\
\text { ramani rawi tuha wanua si jalun ramani... } \\
\text {-- Ilintakan si kunjar ramani subhi... } \\
\text {-- si tguh ramani ndikan... } \\
\text {-- I tunah si mwohok ramani tranta gusti } \\
\text { 3 si anjin ramani ndurukan... } \\
\text {-- I wira si ges ramani binin... }\end{array}$ & $\begin{array}{l}\text { = rama desa di Kasugihan adalah kalang bernama Balawai } \\
\text { ayahnya Rawi dan Tuha wanua bernama si Jalung... } \\
\text { = kalang desa Lintakan bernama si Kunjar ayahnya Subhi } \\
\text { = kalang bernama si Tguh ayahnya Ndikan... } \\
\text { = kalang dari Tunah bernama si Mwohok ayahnya Kranta } \\
\text { gusti } 3 \text { (orang) si anjing ayahnya Ndurukan... } \\
\text { = kalang dari Wra bermama si Ges ayahnya Bining... }\end{array}$ \\
\hline
\end{tabular}




\begin{tabular}{|c|c|c|c|}
\hline $\begin{array}{l}(3 a: 1-2) \\
(3 a: 2) \\
(3 a: 2-3)\end{array}$ & & $\begin{array}{l}\text { rama tpi sirin... ramani sawyan... .. si } \\
\text { nek ramani dalinan... } \\
\text { rama tpi sirin... rama I luitan--si hiri } \\
\text { rama ni datti ... } \\
\text { rama tpi sirin... .- I tigan sugih si } \\
\text { sunkul ramani kodo... }\end{array}$ & $\begin{array}{l}\text { = rama perbatasan...ayahnya Sawyan,...kalang bernama si } \\
\text { Nek ayahnya Dalinan... } \\
\text { = rama dari perbatasan...rama di Luitan:kalang bernama } \\
\text { si Hiri ayahnya Datti } \\
\text { = rama perbatasan...di Tigangsugih:kalang bernama si } \\
\text { Sungkul ayahnya Kodo... }\end{array}$ \\
\hline $\begin{array}{l}(3 \mathrm{a}: 3) \\
(3 \mathrm{a}: 4) \\
(3 \mathrm{a}: 5)\end{array}$ & & $\begin{array}{l}\text { rama tpi sirin...--i paran sibtah rama } \\
\text { ni tarima tuha banua si kanti kaki... } \\
\text { - I kolawukan si guna ramani dara... } \\
\text { rama I turu manamwil milu pinaka saksi } \\
\text { si warana ramani bhukti--si arta ramani } \\
\text { dhyana winehan wdihan... }\end{array}$ & $\begin{array}{l}\text { = rama dari perbatasan...di Prang:kalang bernama si } \\
\text { Btah ayahnya Tarima, Tuha Banua bernama si Kanti... } \\
\text { = kalang dari Kalawukan bernama si Gana ayahnya Dara... } \\
\text { = rama di Turumanganwil turut menjadi saksi bernama si } \\
\text { Warana ayahnya Bhukti, kalang bernama si Arta ayahnya } \\
\text { Dhyana diberi kain (bebed)... }\end{array}$ \\
\hline $\begin{array}{l}30 \text { Gilikan (z.a:13-14) } \\
\text { (II) }\end{array}$ & 845 Saka & $\begin{array}{l}\text { rama tpi sirin I kinwu kalima si bulu } \\
\text { ramani prabhu rama ri amwilan--si bhowi } \\
\text { ta ramani tumwu.. }\end{array}$ & $\begin{array}{l}\text { = rama dari perbatasan di Kinwu, kalima bernama si Bulu } \\
\text { ayahnya Prabhu, ayahnya Amwilan, kalang bernama si } \\
\text { Bhawita ayahnya Tumwu... }\end{array}$ \\
\hline 31 Wulakan (1a:2) & $8(49)$ Saka & tatkala ni--i rawali muan--i wulakan... & $=$ ketika itu kalang di Rawali dan kalang di Wulakan \\
\hline
\end{tabular}

Kalan-watu

\begin{tabular}{|l|l|l|l|}
\hline 32 I'laosan l,or(II/29) & $\begin{array}{l}760 / 778 \\
\text { Saka }\end{array}$ & ammmoda sam--watu pu mungu ... & = anumoda itu kalangwalu beriana pu Munggu \\
\hline
\end{tabular}

\section{Kalan-bungkal}

Kalan-bungkal
\begin{tabular}{|c|l|l|l|}
\hline Kasugihan (la:2) & 829 Saka & $\begin{array}{l}\text {.. inanugrahan irikanan wanua I } \\
\text { kasugihan } \\
\text { de raryan -.- dyah manuku } \\
\text { an sampun inanugrahaken de rakryan -- } \\
\text { bungkal } \\
\text { pinhay I - - irikanan kala kikin si } \\
\text { jamana mantihyan si samanta... }\end{array}$ & $\begin{array}{l}\text { = ...rakryan kalangbungkal bernama Dyah Manuku meng- } \\
\text { anugrahi dea Kasugihan } \\
\text { = setelah dianugrahkan oleh rakryan kalang bungkal }\end{array}$ \\
\hline $\begin{array}{c}\text { Wukajana (xb:8) } \\
(\mathrm{xa}: 11-12)\end{array}$ & 830 Saka & $\begin{array}{l}\text { iken sima samgat - bungkal pu layan } \\
\text { mandiri samgat - bunkal muan samgat... } \\
\text { Jamana, mantihyang bernama si Samana... }\end{array}$ & $\begin{array}{l}\text { = sima itu milik samgat kalangbungkal bernama pu } \\
\text { Layang } \\
\text { berdirilah samgat kalangbungkal dan samgat... }\end{array}$ \\
\hline
\end{tabular}


KALANG: PRASASTI-PRASASTI DARI MASA MATARAM KUNA JAWA TIMUR

\begin{tabular}{|c|c|c|c|}
\hline 33 Balingawan (b:17) & 813 Saka & (...) an san gali juru -- san kumara & $=\ldots$ an sang Gali, juru kalang bernania sang Kumara $\ldots$ \\
\hline $\begin{array}{l}\text { (pl.6) } \\
\text { (pl.7) }\end{array}$ & 823 Saka & $\begin{array}{l}\text { tpi siri(n) muan--gusti wariga winkas... } \\
\text { matan ya de ya nikanan san catur warna } \\
\text { wuluh...wahuta -- }\end{array}$ & $\begin{array}{l}=\text { dari perhatasan dan kalang, gusti, wariga, winkis, } . . \\
=\text { keempa : kasta: wuluh...wahuta, kalang }\end{array}$ \\
\hline 35 Kaladi $\quad(6 b: 4-5)$ & 83I Saka & $\begin{array}{l}\text { I halanan san lumbun -- san sankep... } \\
\text { I waharu san lingah -- san rasut... } \\
\text { I kaladhi ... - san ni wineh... } \\
\text { I padindin san colika wineh ... -. san } \\
\text { gandhi wineh ... }\end{array}$ & $\begin{array}{l}\text { = di Hala.gan bernama sang Lumbung, kalang } \\
\text { bermama sang Sangkep... } \\
\text { = di Wahi.ru bernama sang Linggah, kalang bernama } \\
\text { sang } \\
=\text { Rasut di Kaladhi...kalang bernamasang Ni diberi... } \\
\text { = di Padingdingg bernama sang Colika diberi...kalang } \\
\text { ber- } \\
\text { nama sang Gandhi diberi... }\end{array}$ \\
\hline 36Sugihmanek(b:14-15) & 837 Saka & $\begin{array}{l}\text { rama marata si talandan -- panjaraan san } \\
\text { bandi }\end{array}$ & $\begin{array}{l}\text { = rama marata bernama si Talandang, kalang } \\
\text { Panjaraan di } \\
\text { Limus bermama sang Bandi... }\end{array}$ \\
\hline
\end{tabular}


Kalang dalam tabel itu dapat diperas sebagai berikut di bawah:

1) Kamalagi ( $743 \mathrm{~S}$ ):

dari Pagunungan kalang si Manghem;

dari watak karyyangan Mapatih kalang si Sumdek

kalang (si Wangun) dari desa Sukun

2) Tulangair (772 Saka):

pejabat keagamaan (rakayaran Mapatih Sirikan);

kalang (si Garawuy);

wadwa watak Tiruan kalang (sang Talaga);

Juru di desa Sulangkuning kalang (sang Bantal)

3) Siwagrha (778 Saka): kelompok (kita ta...)kalang

4) Wukiran (784 Saka):

pengurus sawah sang Pamgat tuhakalang pu Nista

5) Tunahan (794 Saka):

rama yang turut menanamkan batas (si Kais)

6) Sri manggala II (746 Saka):

kalang (ramanta) (desa) Salingsingan sebagai saksi

7) Humanding (797 Saka):

mangagam kon kalang (si Rawa dan istrinya (si Andalan);

dari perbatasan kalang (si Wuru)

8) Jurungan (798 Saka):

kalang (si Dana, ayahnya Iram)

9) Haliwangbang (799 Saka):

dari perbatasan kalang (si Pundangil ayahnya Kais);

kalang (si Julung) dari Hanungnang;

kalang (si Dipa) dari Srangan;

kalang (si Glar, si Balun);

kalang (si Rulih) dari gunung Tanayan;

kalang (si Sukra) dari Munggu;

kalang (si Karnna) dari Limpar

istri mangagam kon kalang (si Wadai dan si Gereme);

kalang (si Udi dan si Wisik); klang ron (si Domok)

10) Mulak (800 Saka):

mangagam kon desa Mulak kalang (si Mangawit ayahnya Manghuling);

manguwu ing sima: tuha kalang (si Tunggu ayahnya Gandha);

kalang (si Sadenya ayahnya Gatha);

kalang (si Gusaai ayahnya Suddhi);

dari Tunggayung kalang (sang Wadur ayahnya Tni);

dari Malihyang kalang (si Wangun ayahnya Pandawa); dari Tis...

11) Mamali (800 Saka):

rama desa Mamali kalang (si Pundangin ayahnya Kais); 
kalang (si Gatha ayahnya Dangul)

12) Kwak I (801 Saka):

rama magman di Kwak saat itu kalang (si Pulu ayahnya Sukam);

kalang (si Haning ayahnya Pawi);

rama dari perbatasan Kwak kalang antara lain kalang dari Waharu (si Warju

ayahnya Tahun);

kalang dari desa Halangmanuk (si Sila ayahnya Guday);

kalang (si Wadwa) dari desa Tigawangi

13) Salimar (802 Saka):

ramanta kalang (si Teman);

ramanta Lmah Pakuwangi kalang (si Wama dan si Ngaisi);

ramanta di desa Kandang

14) Wuatantija (802 Saka):

rama di Wuatantija saat itu kalang (si Amwir ayahnya Raghu) dari desa Kupu

15) Taragal (802 Saka): mangagam kon kalang (si Dras dan istrinya ...)

16) Ratawun ( $803 \mathrm{Saka}$ ): daerah perbatasan yang hadirr pada pengukuhan sima kalang (pu Magya) dari desa Limway;

kalang (pu Capah ayahnya Ranggal) dari desa Jruk;

kalang (pu Dalih ayahnya Rimwit) dari Malandang;

kalang (pu Tengeran ayahnya Wadwa)dari desa Kasugihan

17) Ramwi (804 Saka):

Tuhan kalang (si Turunnan);

kalang (si Candra) dari desa Prasada

18) Kurungan (807 Saka):

rama (di Kurungan) saat itu kalang (pu Panggil)

19) Kaduluran (807 Saka): kalang (desa Kaduluran) kala itu;

kalang (si ratna dan istrinya pu Misem);

kalang (punta Bhanu dan pu Bikayi)

20) Mungguantan (808 Saka):

tatrasaksi kalang dari desa Mungguantan (pu Kindong dan pu Sristi)

21) Rongkap (823 Saka):

rama magman kalang (si Manggal dan si Kya)

22) Panggumulan (824 Saka): rama magaman di Panggumulan yang hadirpada pengukuhan sima

kalang (si Pingul ayahnya Uda) sebagai manguwu;

kalang (si Tude ayahnya Bhaisaaakha);

tunggu durung...;

pande dari daerah perbatasan kalang (si Pagar kakeknya Mahu) dari

Suru (watak Hino);

pande kalang (si Taji ayahnya Swami) dari Purud watak Parantungan;

kalang (si Gunakara ayahnya Jaluk) dari Pastamwir 
23) Telang (825 Saka): penunggu (pengelola) penyebrangan kalang ...; kalang dari desa Kalimwaya; kalang dari desa Poh diberi emas ...; kalang dari desa Wakung si (wu...); kalang (si Wgil ayahnya Gadit)

24) Poh/Randusari (827 Saka): dari sima Sanghyang Caitya kalang (?); saksi pengukuhan sima dari perbatasan kalang (si Brita ayahnyaTaram)dari Pulai (watak Galang)

25) Kikilbatu I (827 Saka):

kalang (pu Uwang); kalang (pu Tguh) dari Kakaran;

Kikilbatu II (827 Saka) :

kalang (pu Gubang);

kalang dari Kakaran (pu Tguh)

26) Mantyasih (829 Saka): rama dari perbatasan kalang (?)

27) Wukajana ( 830 Saka):

dari perbatasan kalang (si Knoh ayahnya Santel) dari Mahariman

28) Tajigung (832 Saka): dari perbatasan kalang (pu Bhumi)

dari wanua hulu kalang (pu Tole) dari Bangkal;

kalang (pu Lima) dari Rundungan;

kalang (pu Sagu) dari Wuatan Mas;

kalang (pu Dhara) dari Seser

29) Lintakan (84I Saka):

rama magman kalang (si Balawai ayahnya Rawi);

tuha banua kalang (si Jalung ayahnya Gunu);

kalang (desa Lintakan);

kalang (si Kunjar ayahnya Subhi);

kalang (si Tguh ayahnya Ndikan);

kalang (si Pulakas ayahnya Badha);

kalang (desa Tunah);

kalang (si Mwohok ayahnya Kranta);

kalang (desa (Wra);

kalang (si Ges ayahnya Bining);

kalang (si Anjing ayahnya Ndurukan);

rama dari perbatasan kalang (si Nek ayahnya Dalihan) dari Sawyan;

kalang (si Hiri ayahnya Datti) dari Luitan);

kalang (si Singkul ayahnya Kodo) dari Tigangsugih;

kalang (si Btah ayahnya Tarima);

dari Parang kalang (si Gana ayahnya Dara) dari Kalawukan...;

rama dari Turumangamwil;

saksi (pengukuhan sima) kalang (si Warna ayahnya Bhukti);

kalang (si Arta ayahnya Dhyana)

30) Gilikan (845 Saka):

dari perbatasan kalang (si Bhawita ayahnya Tumwu) dari Kinwu... 
Keterangan ringkas itu mengandung penjelasan bahwa kalang bukanlah jabatan semata tapi lebih menunjuk dirinya sebagai individu ataupun kelompok (Siwagrha 778 Saka: kita ta kalang), termasuk ahli (pande kalang) pula di dalam sejumlah kegiatan-kegiatan lain yang diperaninya. Dan dalam peran dan jabatan itu kalang hampir selalu dalam konteks kalimat seperti berikut kalang- jabatan- nama (diri) keterangan. Contoh: prasasti Tulangair (772 Saka) "wadwa rakarayan mapatih milu kalang sang $d a$..."; prasasti Siwagrha (778 Saka) "kita ta kalang anakbanua gusti wagus tinajar"; prasasti Panggumulan (824 Saka) "rama magaman irikanang wanua sinusuk I panggumulan kalang manguwu si Pingul ramani Uda".

\section{Kalang: Makna dan Pamakaiannya (Referensi dan Makna)}

Dalam setiap bahasa banyak kata memiliki maknanya sendiri-sendiri lepas dari makna kata-kata, tetapi sebaliknya kata memiliki makna dan berperanan (referensi) karena berhubungan dengan kata-kata lainnya. Kalang sebagai morfem memiliki makna berferensi dalam tuturan penuturnya, baik sebagai nomina (kata benda) dan ajektiva (kata sifat) sesuai dengan konteks yang diacunya.

Referensi dan makna dapat berada pada tataran ekstralingual yakni kedudukan kalang sebagai kata yang berada di luar bahasa (dalam hal ini bahasa Jawa Kuna), artinya kalang mengacu hal-hal yang bersifat umum dan dapat diletakkan dalam hubungannya dengan kata, kalimat dan konteks dengan bahasa-bahasa lain di Indonesia (Harimurti Kridalaksana 1990; Verhaar 1996). Yang dimaksudkan adalah kalang dalam makna sebenarnya yaitu lingkaran, garis atau batas yang bertemu gelang kalangan, lingkungan. Mengacu terhadap periannya itu maka kalang oleh para ahli diterapkan kepada asumsi-asumsi antara lain kalang yang bereferensi kepada kemungkinan dibaca sebagai galang. Hal itu terjadi akibat peristiwa perubahan fonem $\mathrm{k}$ (velar tak bersuara)menjadi fonem $\mathrm{g}$ (velar bersuara), artinya penyangga/penunjang; Kalang berhubungan dengan imbuhan an $>$ kalangan = gelanggang dan kalangan setara dengan lingkaran dan lingkungan. Referensi ekstrangual kalang berrelasi kepada makna denotasi yakni menurut makna kata bersangkutan. Dalam konteks prasasti kalang juga diterjemahkan sebagai tempat yang dibatasi guna melangsungkan kegiatan berupa permainan, pertandingan ataupun pertunjukan-pertunjukan tertentu (a.l. persabungan binatang atau hewan tertentu) (Boechari 1958; Kartoatmodjo 1960; 1985; Adiwimarta 1990).

Kalang dengan referensi intralingual berasosiasi pada pemakaiannya yang dimengerti serta berada dalam struktur leksikal Jawa Kuna. Artinya kalang sebagai morfem terletak di dalam hubungan antar kata, kelompok kata, kalimat, konteks dan prasastinya. Karenanya referensi intralingual terkait kepada makna konotasi atau arti 
yang dapat saja muncul akibat daripada penilaian efektif atau emosional dari tuturan dan penuturnya (Suhendra Yusuf 1998). Dalam hal ini referensi tersebut sangat berkait dengan (tuturan penuturnya) yakni struktur birokratis seperti jabatan, peran maupun kedudukan yang disandangnya seperti yang dicatat prasasti. Mengingat identifikasi kalang itu sendiri masih agak sulit diterangkan terutama dalam kedudukannya sebagai morfem yang tergolong archais. Selain dimaksudkan agar kalang dimengerti sesuai waktu tempat dann apa yang dipahami masyarakat Jawa kala itu juga kemungkinan hubungannya dengan kalang yang masih dikenali kini.

Berbagai asumsi para ahli yang dapat dicermati tentang kalang meliputi kalang sebagai per(tukang)an membuka pengertian kalang bergiat menggeluti bidang-bidang pekerjaan ketrampilan yang menghantarnya pada identitas sebagai pengrajin; kalang pun dikaitkan dengan individu, segolongan, sekelompok orang yang tinggal di tempattempat tertentu atau hutan dan mempunyai ketua (de Casparis 1956:26-228); Boechari 1958:69). Karena itu berdasarkan informasi prasasti-prasastinya kalang dapat dipilih ke dalam kategori-kategori sebagai berikut:

- kalang - (diri dan profesinya)

kalang si manghem (pegunungan)

kalang si Dana ayahnya Iram

kalang si Julung (desa Hanungnang)

kalang si Dipa (desa Srangan)

kalang si Glar

kalang si balun

kalang si Rulih (gunung Tanayan)

kalang si Sukra (desa Munggu)

kalang si Karnna (desa Limpar)

kalang si sadenya ayahnya Gatha

kalang si Gusai ayahnya Suddhi

- Kamalagi

- Jurungan

- Haliwangbang

- Haliwangbang

- Haliwangbang

- Haliwangbang

- Haliwangbang

- Haliwangbang

- Haliwangbang

- Mulak

- Mulak

kalang sang Wadur ayahnya Tni (desa Tunggayung) - Mulak

kalang si Wangun (dari desa Malihyang)

kalang (dari desa Tis)

- Mulak

kalang pu Magya (desa Limway)

- Mulak

kalang pu Capah ayahnya Ranggal (desa Jruk

- Ra Tawun

kalang pu dalih ayahnya Rimwit (desa malandang)

- Ra Tawun

kalang si Candra (desa Prasada)

kalang si ratna istrinya Misem

kalang punta Bhanu .

kalang pu Bikayi

- Ra Tawun

kalang si Gunakara ayahnya Jaluk (desa Pastamwir)

kalang pu Uwang

- Ra Tawun

- Ra Mwi

- Kaduluran

- Kaduluran

- Kaduluran

- Panggumulan

- Kikilbatu I 
kalang pu Tguh (desa Kakaran)

kalang pu Gubang

kalang (desa Lintakan)

kalang si Kunjar ayahnya Subhi

kalang si Tguh ayahnya Ndikan

kalang si Pulakas ayahnya Badha

kalang (desa 'Tunah)

kalang si Mwohok ayahnya Kranta

kalang (desa Wra)

kalang si Ges ayahnya Bining

kalang si Anjing ayahnya Ndurukan

- kelompok kalang

- kalang - rama

si Pundangin ayahnya Kais

si Gatha ayahnya Dangul

si Amwir ayalunya Raghu (desa Kupu)

pu Panggil (desa Kurungan)

- rama - tpi siring

si Warju ayahnya Tahun (desa Waharu)

si Sila ayahnya Guday (desa Halangmanuk)

si Wadwa (desa Tigawangi)

pu Magya (desa Limway)

pu Capah ayahnya Ranggal (desa Jruk)

pu Dalih ayahnya Rimwit (desa Malandang)

pu Tengeran ayahnya Wadwa (desa Kasugihan)

(rusak)

si Knoh ayahnya Santel (desa Mahariman)

pu Bhumi

pu Tole (desa Bangkal)

pu Lima (desa Rundungan)

pu Sagu (desa Wuatan Mas)

pu Dhara (desa Seser)

si Nek ayahnya Dalihan (desa sawyan)

si Hiri ayahnya Datti (desa Luitan)

si Singkul ayahnya Kodo (desa Tigangsugih)

si Btah ayahnya Tarima (desa Kalawukan)

si Bhawita ayahnya Tumwu (desa Kinwu)

- kalang - tuha kalang pu Nista

- kalang - tuhan

tuhan kalang si Turunnan
- Kikilbatu I

- Kikilbatu I

- Lintakan

- Lintakan

- Lintakan

- Lintakan

- Lintakan

- Lintakan

- Lintakan

- Lintakan

- Lintakan

- Siwagrha

- Mamali

- Mamali

- Wuatantija

- Kurungan

- Kwak I

- Kwak I

- Kwak I

- Ra Tawun

- Ra Tawun

- Ra Tawun

- Ra Tawun

- Mantyasih

- Wukajana

- Tajigunung

- Tajigunung

- Tajigunung

- Tajigunung

- Tajigunung

- Lintakan

- Lintakan

- Lintakan

- Lintakan

- Gilikan

- Wukiran

- Ra Mwi 
- kalang - rama magman (mangagam kon):

si Pulu ayahnya Sukam

si Haning ayahnya Pawi

- Kwak I

si Dras dan istrinya ...

- Kwak I

si Manggal

si Kya

- Taragal

- Rongkap

si Balawai ayahnya Rawi

- Rongkap

- Lintakan

- kalang - tuha Banua

si Jalung ayahnya Gunu

- Lintakan

- kalang - ramanta

si Teman

si Wama (lmah Pakuwangi)

- Salimar

- Salimar

si Ngaisi (lmah Pakuwangi)

- Salimar

(desa Kandang)

- kalang - (tatra) saksi

pu Kindong

pu Sristi

si Pagar kakeknya Mahu (des Suru)

si Brita ayahnya Taram (Pulai)

si Warana ayahnya Bhukti

si Arta ayahnya Dhyana

- kalang - maparahu

(desa Kalimwaya)

(desa Poh)

(desa Wakung)

si Wgil ayahnya Gadit

- kalang - pande kalang si taji ayahnya Swami (desa Purud)

- kalang - manguwu

si Pingul ayahnya Uda

si Tude ayahnya Bhaisakha

- kalang - tunggu durung

- Mungguantan

- Mungguantan

- Mungguantan

- Poh

- Lintakan

- Lintakan

- Telang

- Telang

- Telang

- Telang

- Panggumulan

- Panggumulan

- Panggumulan

- Panggumulan

Dari catatan prasasti itu peran yang paling sering disandang kalang adalah rama (yang dituliskan dengan vokal a panjang) yang diuraikan menjadi $r a-$ (r)ama. Ra dalam bahasa Jawa Kuna merupakan kata sandang penghormatan (honorefik prefik) yang ditujukan kepada ama > rama, maka rama yang dimaksudkan di sini adalah kepala, ketua, pemimpin atau yang dituakan atau (yang dianggap) sesepuh, pinisepuh di lingkungan desa (wanua). 
Di samping itu rama diberi referensi mangagam, mag(e)man-kon, secara lengkap dibaca rama mengagam (mageman) kon; rama merata atau rama saja. Jikalau rama $m a(n) g(a) m a n k o n$ adalah pemimpin (ketua) desa yang masih memegang (magaman) perintah (kon), maka sebaliknya rama marata $($ Skr.ram= diam) telah berhenti dari jabatannya karena dianggap telah tua dan walau tetap (di)aktif(kan) sebagai tetua (tuwa-tuwa), sesepuh, pinisepuh (de Casparis 1956, cat.23; Boechari 1958).

Kalang di dalam kedudukannya sebagai rama terutama dalam perannya sebagai rama I tpi siring (Jawa:tpis wiring) secara luas diterjemahkan kepada desa/daerah di tepi atau di samping dan berbatasan langsung dengan desa sima. Secara umum masyarakat Jawa kala itu mengenal pola pemukiman pokok yaitu panyatur desa dan pangasta desa artinya suatu desa dikelilingi empat desa yang terletak diarah empat penjuru mata angin dan kelipatannya terdiri dari delapan, enambelas; juga kelipatan tiga. lima, enam dan kelipatannya tetapi istilahnya belum diketahui dalam prasasti (Boechari $1958 ; 1980: 330-333$ ). Pola pemukiman itu berada di lingkungan teritorial raja, watak, wanua dan tepis wiring merupakan batas wilayah? Sebagai saksi peristiwa pengukuhan sima, saat sama kalang juga menjabat kedudukan-kedudukan tertentu, di antaranya manginu (Mulak 800 Saka; Panggumulan 824 Saka); Pande (Panggumulan 824 Saka); tunggu durung (Panggumulan 824 Saka); juru (Tulangair 772 Saka; Balingawan 813 Saka); tuha (Wukiran 784 Saka; Mulak 800 Saka; Ramwi 804 Saka) abdi dalem ( $w a d w a)$ seorang pejabat tinggi, dan (rakryan).

Kalang manguwu adalahh kalang menjabat sebagai manguwu, berasal dari kata dasar kuwu $>$ kubu yang kini masih dikenal di dalam kosakata bahasa Indonesia dengan terjemahan benteng, kemah juga tembok (pagar) keliling untuk pertahanan atau keamanan dari serangan musuh, karenanya kubu juga merujuk kepada pusat kegiatan. Kuwu (Jawa Kuna) hampir sepadan dengan rama yakni kepala desa atau lurah, sedang manguwu $>$ awalan ma dengan ng (nasal) $+(\mathrm{k}) \mathrm{uwu}=$ menyatakan pekerjaan atau suatu keadaan yang ditunjuk kata kuwu. Jikalau kuwu . kubu maka manguwu dihubungkan dengan (tukang) membuat kubu sebagaiman diterjemahkan oleh Boechari (1958). Kosakata Sunda pun mengenal makuwu - makuwon artinya mendiami (orangnya)-> pakuwuan-pakuwon merujuk terhadap bangunan (rumah) berikut pekarangannya (Robins 1983; Soeriadiradja dan kats 1982; LBSS 1984).

Bagaimana kalang yang bertugas sebagai makmit $\operatorname{sima(kamulan)}$ atau penunggu/ penjaga bangunan (suci) leluhur masih belum jelas benar. Tapi kalang dengan tunggudurung bereferensi kepada tunggu artinya menunggu, m(p)enjaga); durung adalah lumbung padi, kalang yang bertugas menjaga lumbung padi seperti yang dikenal di Bali sekarang. 
Pande kalang (Panggumulan 824 Saka) terdiri dari kata pande dan kalang. Pande merupakan hasil gabungan bunyi kata dasar dan imbuhannya (samdhi dalam) seperti ditunjukkan oleh pandai $+I>$ panda $(a+i=e$ ) maka dibaca pande (Soebadio 1983). Pun dalam bahasa Indonesia pandai berkenaan dengan keahlian, ketekunan, dan kecermatan yang diperoleh melalui latihan terus-menerus, atau sering dilakukan yang lambat laun menjadi pengalamannya; pula diterjemahkan ahli tempa (logam) dalam arti seluas-luasnya (Juynboll 1913; Zoetmulder 1982; Adiwimarta 1990).

Maka pande kalang di sini setara dengan pande wsi ( $=$ ahli menempa besi), pande mas (= ahli menempa emas), pande tambra (= ahli menempa tembaga), pande kangsa (= ahli menempa perunggu), pande salaka ( $=$ ahli menempa perak), pande dadap (= ahli membuat tameng), pande dang (= ahli membuat dandang), pande singya-singyan (= ahli membuat senjata) dan lainnya. Pekerjaan yang tergolong sebagai ahli sebagaimana kata yang diacunya (pande) itu membutuhkan kecakapan dan kecermatan khusus yang biasanya dilakukan oleh seorang pengrajin.

Satu hal yang masih perlu dicermati adalah kalang dalam kaitan dengan kata pande. Di dalam sumber-sumber tertulis dari Bali (prasasti maupun karyasastra), istilah ataupun sebutan pande selalu mengacu kepada atau sesuai jenis bahan yang ditempanya (dikerjakannya) atau yang diolahnya dan mereka tergabung ke dalam kelompok undhagi. Berdasarkan sumber tertulis (lontar Hastakosali) kata undhagi diterangkan sebagai (w)undagi yang diuraikan menjadi wu = ngaran Siwa (nama dewa Siwa); wit $=$ ngaran wit (nama pohon atau asal $>$ wiwitan $=$ leluhur); gi $=$ ngaran sarira (nama tubuh/badan). Sedang dalam lontar Wiswakarma diperoleh keterangan bahwa (w)unda(ha)gi berhubungan erat dengan seorang bernama Sanghyang Wiswakarma yang ditugaskan Bhatara Guru untuk turun ke dunia dan menjelma sebagai undagi (Kartoatmodjo 1985:41-42). Kisah serupa juga diceritakan dalam Tantu Pangglaran dan Carita Parahiyangan sumber tertulis yang mengisahkan asal-usul diperolehnya pengetahuan manusia, kaitannya dengan tukang dan pertukangan, keahliah manusia mengolah lingkungan dunia (Pigeaud 1924).

Namun keahlian (pande) yang ditunjuk oleh kata kalang itu sendiri belumlah jelas meskipun referensinya menunjuk terhadap pande. Apakah pande kalang di sini berhubungan dengan ahli mengolah (mengerjakan) kalang. Sementara dalam konteks prasasti, kalang tidak bereferensi terhadap pande melainkan berlaku sebaliknya, kalang tidak diletakkan dalam kelompok undahagi tetapi kelompok tersendiri dan masing-masing memiliki ketuanya tuha/juru kalang, tuha/juru undahagi. Halnya tuha yang kerap berganti juru adalah setara dengan pemimpin atau pengawas, pejabat ataupun segolongan yang biasanya dipilih karena dianggap tertua serta ahli (pengalaman) dan sudah lama menduduki jabatannya sebagaimana juga kalang sebagai tuha (banua); tuha adalah ketua dan banua (wanua) atau desa? Belum tegas 
apakah wanua (banua) dalam konteks tuha banua juga sama artinya dengan kepala/pemimpin desa; atau tuha banua merupakan istilah lain menyebut rama mengagam (kon)?

Kalang adalah individu/kelompok dihubungkan dengan batu (watu - wungkal), daun (ron). Keduanya dikenali termasuk kepada jenis-jenis bahan sumberdaya yang diperoleh dari alam (hutan); kalang memiliki pemimpin yakni tuha, juru; kegiatan yang menghantarnya terhadap profesi atau keahlian khusus pande kalang, dan sebagai pande, kalang dibedakan dengan undahagi tetapi bergiat sendiri dalam perannya dan sebagai warga masyarakat desa; anung maturus = yang membantu menanamkan (batu) sima; mang(k)uwu, makmit sima(kamulan), tunggudurung berhubungan dengan membuat, menjaga, atau mengelola bangunan, menjaga penyebrangan di (tepi) sungai dengan perahunya sekalian (prasasti Telang 825 Saka).

Kalang- pemimpin daeran (rama) tidak hanya aktif saat memangku jabatan (rama mangagam (kon)) tetapi juga saat telah pensiun (marata). Khususnya saksi yang sengja diundang, sehingga kehadirannya kerap diterangkan dengan kahop pangangkat panungsung muang sangunira mulih (biaya untuk pergi dan pulang). Sebagian besar mereka berada di daerah perbatasan (wanua tpi siring) yang termasuk dalam pola pemukiman panyatur atau pangasta desa. Dalam hal ini Boechari 1977a dan b) menegaskan bahwa desa-desa tpi siring antara lain dapat dipakai untuk melacak batas suatu wilayah. Apa yang digiati kalang mungkin seperti dimuat prasasti Haliwangbang (799 Saka:26-4-5) anakbining mangagam kon kalangron si wadai kalangron si gereme kalangron si domok (Boechari 1958); prasasti Plaosan Lor (760/778 Saka) anumoda sang kalangwatu pu munggu; prasasti Kasugihan (829 Saka:1a.2) inanugrahan irikanang wanua I kasugihan de rakryan kalangbungkal dyah manuku (Poerbatjaraka 1922) prasasti Wukajana (830 Saka:xb.8); ikeng sima samgat kalangbungkal pu layang; (xa:11-12) mangdiri samgat kalangbungkal muan samgat...

Dari konteks itu kalang bereferensi dengan ron (daun) dan wungkal bungkal/watu (batu). Daun maupun batu termasuk jenis-jenis bahan yang berasal dari sumberdaya alam. Kalang ron dalam kaitannya dengan daun, apakah kala itu daun merupakan salah satu kebutuhan pokok? Mengingat kalangron berada dalam konteks dengan prasasti sima maka secara langsung pula dihubungkan dengan peristiwa upacara sima yakni aneka ragam saji-sajian dan hidangan yang disajikan dalam peristiwa upacara sima. Disebutkan dalam prasasti, dikala seseorang menambah santapannya tak disebut menambah makanannya melainkan menambah daunnya (menambah I ronnya). Lien Dwiari Ratnawati (1999) mengkategorikan pelbagai hidangan dan saji-sajian (makanan) upacara yang dipilah menjadi tiga kelompok yakni sajian (makanan) untuk 
dewa yang tidak boleh dimakan hadirin; sajian (makanan) untuk dewa dan boleh dimakan hadirin sesuai upacara; dan makanan yang khusus disediakan untuk hadirin. Klasifikasinya terhadap makanan adalah hasil pengalaman terhadap masyarakat Baliage di desa Tenganan Pegringsingan dibandingkan dengan sajian (makanan) dalam peristiwa upacara pengukuhan sima (prasasti). Dengan alasan desa Tenganan merupakan desa kuna yang dalam kehidupan sehari-hari masyarakatnya masih termasuk 'kukuh' berpegang terhadap tradisi-tradisi lama dan kesinambungannya dengan sejarah perkembangan budaya masa lampau (Dwiari Ratnawati 1999). Disebutkan bahwa sajian dan hidangan itu diletakkan dan disusun ke dalam wadahwadah yang terbuat atau dibuat dari kulit bambu (ancak, kepe dan dulang/wanci) yang dilapisi daun (aren/enau) dan dianyam sedemikian rupa berupa lembaran, disebut eledan.

Peristiwa upacara itu tidak hanya terjadi insidentil atau sekali saja, melainkan berkalikali dan teratur, karenanya eledan yang diperlukan tentu dalam jumlah yang cukup banyak dan bervariasi dari ukuran kecil hingga ukuran besar, disesuaikan dengan jenis kebutuhan dan kapasitas hidangan, lagi pula daun sifatnya sekali pakai setelah acara selesai langsung dibuang. Sejalan dengan pernyataan Niels A. Mulder (1973) dan Franz Magnis-Suseno (1985) bahwa bangsa Indonesia, khususnya orang Jawa memiliki sifat seremonial dan hampir tiap-tiap peristiwa yang dianggap penting baik menyangkut kehidupan seseorang, bersifat keagamaan atau kepercayaan maupun mengenai usaha seseorang dalam mencari penghidupan, pelaksanaannya selalu disertai upacara. Dimengerti daun termasuk kebutuhan pokok yang harus selalu tersedia dalam jumlah cukup banyak pada setiap berlangsungnya upacara dan keperluan sehari-hari. Di dalam prasasti yang diacu di sini penyediaan daun itu dikelola oleh istri kepala desa.

Halnya kalang wungkal (bungkal) atau kalang watu diperankan oleh seseorang rakryan yang bernama Dyah Manuku dan seorang samgat bernama pu Layang, sedangkan kalang watu diperani oleh seseorang sang bernama Pu Munggu. Rakryan dan samgat adalah gelar yang cukup tinggi (di bawah raja) dan terpandang di dalam susunan birokratis masyarakat Jawa Kuna. Lazimnya pejabat-pejabat golongan ini memiliki daerah lungguh disebut watak (Jawa: tanah bengkok) sebagai wilayah kekuasaannya dan membawahi desa-desa di sekitarnya. Tanah lungguh itu tertera sebagai salah satu gelarnya. Maka gelar rakryan biasanya identik dengan gelar lungguhnya, diikuti kata sandang $p u$ atau dyah serta nama lahir. Namun sejauh data berbicara khususnya periode Mataram Kuna belum dijumpai watak kalangwungkal, wungkal atau kalangwatu melainkan (watak) munggu (antan), (watak) manuku dan (watak) layang (Damais 1970). 
Besar kemungkinan kalangwatu merupakan julukan yang khusus diberikan sesuai dengan profesi kegiatannya.

Sebagian besar prasasti bertema sima berhubungan dengan pemeliharaan dan biaya pengelolaan suatu bangunan suci. Suatu tanah dikukuhkan menjadi sima, statusnya berbeda dengan tanah-tanah lainnya dimana hasil pungutan pajak dan denda-denda yang harusnya masuk kas kerajaan selanjutnya dilimpahkan bagi keperluan menyediakan saji-sajian; upacara-upacara pemujaan bhatara di dalamnya; pemeliharaan bangunan suci yang bersangkutan dengan sima itu. Boechari $(1958 ; 1980)$ menjelaskan suatu bangunan suci memiliki tanah-tanah perdikan berupa rawa-rawa, sawah, ladang, kebun, taman, pagagan, padang rumput, bukit, lembah dan tepian. Seluruhnya diperuntukkan bagi biaya-biaya mempersembahkan saji-sajian upacara keagamaan yang dilaksanakan secara berkala (setiap hari, setiap bulan, dua kali setahun, setahun sekali). Selain itu di sekitar bangunan suci terdapat permukiman penduduk yang mengelolanya; pemukiman pendeta yang mengurus dan memimpin upacara keagamaan, pemukiman budak-budak yang berkewajiban merawat bangunan suci setiap hari, dan bangunan-bangunan sementara ataupun permanen yang diperlukan bagi mempersiapkan upacara.

Dari sejumlah pesan prasasti bertema sima itu tergambar betapa banyaknya bangunan suci itu, termasuk pula bangunan-bangunan penyerta lain bagi yang mengelolanya. Bangunan-bangunan tersebut tentu saja dibuat dari batu khususnya bangunan suci (keagamaan) sebagaimana sisa-sisanya yang disaksikan kini. Sementara itu bangunanbangunan yang tergolong sementara oleh W.F. Stutterheim (1940) dikhususkan untuk memuja raja-raja yang telah wafat. Mungkin selain menggunakan bahan-bahan yang sifatnya permanen seperti batu pun digunakan bahan bangunan lain sebagai pelengkap seperti kayu, bambu, ijuk, dan rumbia sebagai halnya (di Bali) sekarang dan bangunan-bangunan tradisional lainnya.

Sang Kalangwatu Pu Munggu yang digoreskan salah satu bangunan di Plaosan Lor (760-778 Saka) belum diketahui, kecuali dapat diterangkan sebagai seseorang yang turut mengiringi, mempersembahkan (anumoda) salah sebuah bangunan kepada rajanya ataukah sebagai yang menyediakan bahan bangunan (batu) bagi kebutuhan bangunan (suci) (de casparis 1958). Kata sandang sang yang dipakainya menunjukkan bahwa kalangwatu berasal dari golongan tertentu yang mungkin dapat disejajarkan dengan rakryan atau karena jasa-jasa atau profesinya?

Kalang- rakarayan adalah hal yang masih perlu ditegaskan. Jikalau kalangwungkal merujuk kepada gelar rakryan, maka kalangwatu cenderung diinterpretasikan sebagai seseorang berasal dari tingkatan lain seperti bungkal, satu dan lainnya sinonim artinya batu. Mungkin kalangwungkal - kalangwatu dapat dibandingkan dengan gelar yang 
disandang oleh rakryan (bawang) mapapan dan rakryan (bawang) watu. Abu Sidik Wibowo (1979) menerangkan bahwa (bawang)watu bersinonim dengan (jasun)wungkal menunjukkan tanah lungguhnya berada di dataran tinggi, sebaliknya (bawang)mapapan menunjukkan bahwa tanah lungguhnya berada wilayah di dataran rendah.

Kalangwungkal/bungkal dihubungkan dengan Dyah Manuku yang pernah dipakai oleh Rakai Patapan dan oleh Rakai Pikatan, tokoh-tokoh yang pernah bertahta sebagai raja pada masa Mataram Kuna. Dyah Manuku (Sunda: (n)-tekung = menutup) merupakan saat dimana seseorang memasuki masa menutup diri dari dunia luar (LBSS 1984). Berbeda dengan Pu Layang yang bergelar samgat $>$ sang pamegat sungguh-sungguh menunjuk nama dan gelar seseorang pejabat kala itu (Boechari 1984). Akan tetapi identifikasi terhadap tokoh-tokoh tersebut tidak diuraikan lebih luas sebab tulisan ini lebih dititikberatkan kepada referensi kalang serta kemungkinan identifikasinya.Apabila kalangwungkal-kalangwatu dapat dibandingkan dengan gelar rakryan (bawang) mapapan dan rakryan (bawang) watu, maka asumsi Abu Sidik Wibowo (1979:19-36) berlaku bahwa kalangwungkal-bungkal dengan gelar rakryan menunjuk seseorang yang bertempat tinggal di dataran tinggi (highland), sedangkan kalang-watu dengan gelar atau kata sandang sang merujuk kepada yang bergiat pada batu atau pengusaha sumberdaya alam berupa batu (?).

Jikalau pendapat itu diterima maka kalang-> kalang-an = galang->galang-an- $>$ adalah juga gelanggang kehidupan, individu atau kelompok menempati dan menyatu dengan lingkungan tertentu yang melahirkan dan turut membentuk ciri dalam arti yang seluas-luasnya. Lingkungan hidup dan berkehidupan yang dapat merujuk kepada hutan, gunung, pegunungan, dataran tinggi, dataran rendah dan dimana pun kalang menetap serta menjadikan nilai dirinya. Berpegang kepada prasasti, sebagian besar kalang berada di perbatasan (tpi siring) dengan desa-desa yang telah berstatus sima maka istilah tpi siring adalah juga kalang(an) merujuk kepada individu/kelompok kalang atau pemukiman kalang itu sendiri.

Tentu saja permukiman itu masih berada dalam pola penyatur desa atau pengasta desa. Bahwa desa-desa itu tidak berada di suatu tempat yang terisolir, melainkan berdekatan dengan desa-desa dan diikat oleh hubungan keturunan. Hubungan keturunan dalam keperluan saling melindungi, anak laki-laki mewarisi bagian yang sama dan tinggal bersama-sama dengan ayahnya. Keluarga-keluarga tersebut melakukan perluasan keluar hingga generasi berikutnya dan berkembang menjadi konsentrasi keluarga semacam clan atau kelompok masyarakat? (Tome dan Kartodirdjo ed. 1977). Kian lama bertambah dan meluas melalui batas-batas desa, bagi desa-desa yang berbatas pegunungan perluasan itu makin lama makin ke dataran tinggi, membuka lahan-lahan baru di hutan-hutan sekitarnya. 
Dalam ekosistem inilah kalang menjalani proses pembudayaannya dan merealisasikan dirinya hingga memperoleh keahlian mengolah hutan dan sarat dengan berbagai sumberdaya, tidak sekedar batu, daun, juga kayu, bambu dan lainnya. Dalam pengertian kalang sebagai kelompok atau golongan itu berada dan hidup di dalam lingkaran, lingkungan yang merupakan batas pemukiman atau komunitas tertentu.

Pemukiman berpola memusat itu membujur mengisi lahan yang lebih rendah (lembah) hingga ke lahan-lahan perbukitan (gunung-pegunungan) sebagai batas desa. Dapat dimengerti pula hubungan di antaranya pun tiada terputus melainkan tetap melangsungkan komunikasi dua arah. Pada satu pihak menempati dataran lebih tinggi mengolah sumberdaya dan berperan sebagai pemasok berbagai kebutuhan yang diperoleh dari sumberdaya alam, di pihak lain penduduk yang berada di lembah (dataran rendah) adalah konsumen dan di antaranya selalu terjalin ikatan saling membutuhkan.

\section{Kalang, identifikasi Nilai Budaya Masyarakat Jawa}

Prasasti adalah dokumen resmi sebagai saksi peristiwa-peristiwa penting menurut kepentingan si pembuat dokumen pada zamannya, karena itu prasasti tidak melestarikan kejadian-kejadian individual serta hal-hal unik yang dialami seseorang atau segolongan, khususnya kenangan abdi dalem-abdi dalem merasakan pekerjaannya, keahliannya, hubungan sosialnya, serta kehidupan ekonominya. Mengetahui identifikasi kalang, maka dibandingkan dengan sumber-sumber lain, salah satunya adalah cerita-cerita lisan, mitos-mitos yang beredar di kalangan masyarakat Jawa.

Betapapun kadarnya berbeda, sejarah lisan yang tersimpan di dalam cerita-cerita rakyat tidak patut diabaikan. Pada dasarnya cerita-cerita di kalangan masyarakat tradisional merupakan salah satu bentuk pengetahuan dan perlambangan nyata dari pengalaman sosial suatu kebudayaan, kearifan terhadap lingkungan fisik tempat melangsungkan kehidupannya. Inti cerita merujuk kepada tema yang sama walaupun tokoh-tokoh yang ditampilkannya telah diadaptasikan sesuai kebutuhan dan pengetahuan setempat (Stephanus Djajawanai 1982/1983).

Kalang sebagai kelompok masyarakat yang bertahan dengan nilai-nilai budaya dan relevansinya dengan masa lampau itu terendapkan dalam mitos yang selanjutnya melahirkan cerita di kalangan masyarakat Jawa. Cerita rakyat tentang kalang diuraikan dalam karangan Lelono (1989) berkembang dalam berbagai versi namun yang mencolok antara lain bahwa kalang memiliki ekor. Yang dimaksud cerita rakyat adalah tuturan yang membentangkan terjadinya suatu peristiwa, hal, ataupun kejadian 
zaman dahulu yang hidup di kalangan suatu masyarakat yang diwariskan secara lisan dan turun temurun. Versi cerita tentang kalang itu demikian banyak dan beragam namun induk ceritanya bertema 'sama' yakni asal-usul sejarah kalang dan keberadaannya di dunia. Karenanya yang diambil sebagai contoh di sini hanya dua saja.

Versi pertama: Konon ada seorang pangeran yang tengah berburu di hutan, pada suatu waktu ia ingin berhajat kecil dan membuang air seninya pada sebuah tempurung. Seketika muncul seekor babi betina yang tengah dahaga, saat nampak air dalam tempurung dan sang babi pun meminumnya akibatnya sang babi mengandung. Beberapa bulan kemudiab sang babi melahirkan bayi putri tetapi ditinggalkannya di hutan. Kemudian ditemukan dan dirawat oleh seorang janda sehingga tumbuh dewasa dan berparas elok serta pandai menenun.

Pada suatu hari sebuah teropongnya terjatuh, ia segan mengambil dan berucap; "Siapa yang menolong mengambilkan teropongnya, maka jika perempuan dijadikan saudaranya, tetapi jikalau laki-laki dijadikan suaminya". Untung tiada diraih malang tak dapat dilerai, seketika munculah anjing jantan menyerahkan teropong tersebut maka sang putri pun memenuhi sumpah, menikahi anjing jantan. Melalui pasangan ini lahir bayi laki-laki dan tumbuh menjadi pemuda tampan diberi nama Jaka Sona (Sona = anjing). Ia senang berburu hingga suatu waktu tiada seekor binatangpun, saat itulah ia melihat (hewan) babi, tak pelak dibunuhnya tanpa mengetahui bahwa babi itu sesungguhnya adalah nenekdanya. Ibunya murka lantas mengusir Jaka Sona, ia pergi menjalani kehidupannya dari hutan ke hutan dan sejak itu Jaka Sona dianggap cikalbakal kalang.

Versi kedua: Jaka Sona (Jaka Kalang) lahir dari hasil perkawinan Rara Kasihan yang menyamar sebagai Temon (Rara Jonggrang), putri Prabu Gopala dengan putra Dharmawangsa dari kerajaan Pengging bernama Bandung Bandawasa yang dikutuk jadi anjing. Dari perkawinan itu lahirlah Jaka Kalang, setelah dewasa mengabdi kepada kakeknya dan diangkat sebagai mentri kehutanan bergelar Tumenggung Kalangdaya yang mengepalai $u n d a(h a) g i$ kayu.

Di kalangan masyarakat Bali, Jaka Sona yang beragama Hindu diusir dari tanah asalnya lalu pergi ke Jawa dan Raden Ayu Ambarwuyung yang beragama Islam. Merekja menjalin asmara sehingga Raden Ayu hamil dan mengharuskan pindah ke Petanahan-Kebumen. Mereka dianggap cikal-bakal kelompok masyarakat kalang dan turun-temurun menyebar di daerah-daerah Ambal-Kebumen, Ngotho, TegalgenduYogyakarta, Sragen dan banyuwangi. 
Disebutkan bahwa selain cerita rakyat, kalang juga dikenal dengan tradisi upacara obong, upacara membakar (obong) mayat dengan membakar boneka, lambang orang yang telah wafat dan dilaksanakan pada hari keseribu. Kalang terdiri dua kelompok yakni kalang-obong (kalang besmen) dan kalang-kamplong. Kalang obong menganggap dirinya keturunan pancerlanang- pihak ayah (patrilineal), sedangkan kalang-kamplong dari panceristri- pihak ibu (matrilineal). Menurut aturan kalang kamplong yang berdarah kalang dari pihak ibu itu karena si ibu menikah dengan orang yang bukan dari lingkungan kalang dan pihak ini dianggap tidak dibenarkan melakukan upacara obong.

Hubungan kalang dengan satwa-satwa tertentu (anjing, babi) adalah cermin homoginitas atas gagasan universal dengan tema sentral seorang yang tidak diketahui asalnya dan selanjutnya menurunkan kalang. Hubungan kalang dengan lingkungan hutan antara lain diinterpretasikan dengan ciri fisiknya yang konon memiliki ekor, organ tubuh yang lebih dikenali sebagai ciri utama satwa itu, hakekatnya upaya mempertautkan kalang dan lingkungan fisiknya. Cerita rakyat yang mengisahkan kalang itu dapat dilihat dalam bagan berikut:

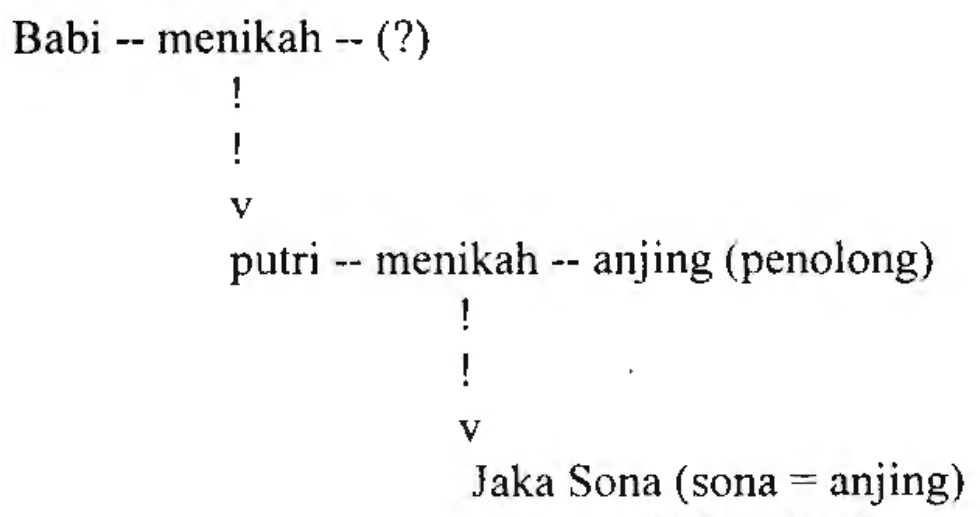

(KALANG)

Tokoh ayah belum jelas kecuali berhubungan kepada seseorang yang berstatus lebih tinggi kemudian melakukan hubungan dengan seseorang perempuan yang tinggal di hutan. Karenanya sang ayah tidak disebutkan, tetapi keturunanya memperoleh hak penuh atas tradisi upacara obong. Tokoh yang melahirkan dilambangkan satwa babi yang mengawali kehidupan kalang mengingatkan kepada konsep dewi ibu atau kultus dewi ibu yang merupakan bagian dari kebudayaan masyarakat agraris yang dianut pada akhir zaman batu tua sebelum hadirnya Hindu-Budha dan kedudukannya kian penting sejak manusia mengenal cara-cara bercocoktanam. Dewi ibu adalah pelindung, pemelihara sumber kehidupan yang dipersonifikasikan dengan tanah, yang melahirkan tanam-tanaman dan kebutuhan-kebutuhan hidup lainnya yang termasuk sebagai sumberdaya alam. 
Dalam perkembangan selanjutnya dewi ibu dipuja melalui berbagai aspeknya, sesuai tempat, lingkungan kehidupan dan persepsi kepercayaan masyarakatnya (Periksa Hariani Santiko 1982). Mungkin itulah yang menyebabkan kelompok kalang berkait dengan satwa babi, mungkin satwa inilah yang dianggap paling dapat memenuhi kebutuhan hidupnya sehari-hari (setidak-tidaknya dikonsumsi sebagai protein hewan). Halnya dengan satwa anjing yang merupakan hewan peliharaan yang paling jinak, dan bersahabat dengan manusia, pula dapat dilatih sesuai dengan kepentingan manusia antara lain teman bermain, teman berburu, bekerja dan menjaga keamanan. Kemampuan-kemampuan yang merujuk kemungkinan kepada sesuatu/seseorang yang setia, kerabat atau pengawal.

Kisah-kisah tentangnya yang beredar dan berkembang di kalangan masyarakat merujuk kepada kalang dengan peran-peran dan kegiatannya mencerminkan rangkaian tingkah laku berpola dalam dimensi waktu dan konteks pembentukannya sebagai sisi kehidupan masyarakat Jawa kala itu. Dalam arti kalang sebagai mahluk sosial dengan pengetahuan dan lingkungan pengalamannya menjadi kerangka landasan yang berfungsi sebagai pengendali keberlangsungan kehidupannya.

Sejalan dengan pendapat Parsudi Suparlan $(1980 ; 1997)$ yang menyatakan bahwa cara hidup menentukan pandangan hidup seseorang, begitu pandangan hidup tercipta maka cara hidupnya turut ditentukan olehnya. Hakekatnya secara struktural manusia adalah pelaku yang bertingkahlaku di lingkungan yang mengkondisikannya. Lingkungan yang bersifat dinamis itupun dapat berubah karena aktivitas dan alter-natif pelaku. Pula manusia sebagai mahluk hidup memiliki kebutuhan dasar sedikitnya ada lima yaitu kebutuhan fisiologis, rasa aman, afiliasi, harga diri, dan pengembangan potensi. Jikalau kebutuhan hewan lebih terpusat pada dua hal utama (kebutuhan fisiologis dan rasa aman) yang dipenuhinya secara instingtif. Sebaliknya manusia tidak memiliki kemampuan untuk bertindak secara otomatis berdasarkan insting, maka manusia berpaling pada kebudayaan yang mengajarkannya cara hidup. Kebudayaan adalah alat manusia dan kemanusiaan sebagai survival kit, bertindak dengan kekuatan akalnya membaca simbol-simbol yang terdiri dari seperangkat gejala di dalam lingkungannya (Budhisantosa 1982/1983; Ernst Cassirer 1990). Maka kalang identik dengan masyarakat Jawa yang hidup, menjaga dan mengelola sumberdaya-sumberdaya alam yang menjadi hak ulayat sumber kekayaan desa, tempat tumbuh beraneka jenis flora dan fauna. Diketahui bahwa hutan merupakan masyarakat tumbuhan dengan sejumlah besar tumbuhan dengan vegetasi yang rapat, sangat luas, terjadi secara alami tanpa campur tangan manusia (Yando Zakaria 1994).

Jelaslah, hutan, lingkungannya serta seluruh sumberdayanya yang yang telah membentuk kalang merealisasikan kreatifitasnya sebagai kelompok masyarakat, sebaliknya kalang sebagai pelaku mengolah lingkungan hutan itu menjadi manusiawi. 
Dengan kata lain hutan adalah wadah yang telah memberinya nilai-nilai kemanusiaan yang diartikulasikan ke dalam keterjalinan organis dan dilestarikan pada tempatnya yang layak yakni kebudayaannya.

\section{Penutup}

Disadari bahwa penjelasan mengenai kalang sangat ringkas, namun ada hal patut disimak bahwa sebagai kelompok masyarakat dengan mata pencaharian tradisional mereka menyalakan vitalitas positip dalam posisinya yang marjinal. Terutama kemampuannya memilih strategi serta menyesuaikan diri sebagai tanggapan terhadap tersedianya informasi yang terkandung dalam lingkungannya itu, tidak semata-mata perannya sebagai (pelaku) melainkan secara aktif memperkenalkan faktor-faktor supra organik dalam jaringan kehidupan.

Di satu sisi kalang memacu solidaritas guna kelangsungan dan keselamatan kehidupannya, di mana lingkungan hutan menjadi tempat yang pantas dihuni secara natural, di sisi lain lingkungan merupakan bagian dari dirinya itu telah diolah menjadi bermakna serta membuahkan manfaat bagi orang lain.

Di lingkungan di mana mereka berada dan tinggal selalu memacu dan mengembangkan daya ciptanya menjadi lebih baik dan terarah. Bukankah itu berarti, kalang sebagai kelompok masyarakat yang 'konon' dianggap hina dan berasal dari golongan rendah itu sesungguhnya mampu membaca simbol-simbol dan gejala-gejala di lingkungan yang mengkondisikannya?

Sejalan laju modernisasi dan pembangunan di segala bidang, telah terjadi pertumbuhan yang sangat besar di berbagai sektor kehidupan. Keadaan itu mengakibatkan timbulnya transformasi dan pergeseran nilai sosial budaya, ekonomi dan politik. Nampaknya kalang dan kearifannya justru survive dengan nilai-nilai tradisionalnya yang dahulu pernah merupakan simpul-simpul kekuatan yang menghantarnya dari waktu ke waktu. Tiada lekang arus bahkan sebaliknya lentur mengiringi perubahan zaman tanpa harus kehilangan kepribadiannya ditengah-tengah lingkungan yang tertimpa era modernisasi.

Sesungguhnya alam tradisional di masa lampau adalah gudang yang menyimpan sekian banyak bukti nyata tentang akar kebudayaan sekaligus menjadi ciri yang membedakannya dengan bangsa-bangsa lain. Jikalau profesi-profesi modern tumbuh menjadi individu maka kalang justru menjadi penyangga spiritualisme dan profesionalisme zamannya. 


\section{KEPUSTAKAAN}

A.S. Wibowo, 1979. Prasasti Alasantan Tahun Saka 851, Majalah Arkeologi Th.II. No. 3. Januari 1979. Diterbitkan oleh Lembaga Arkeologi FSUI.

Adiwimarta, 1990, Kamus Besar Bahasa Indonesia. Balai Pustaka (Departemen Pendidikan dan Kebudayaan).

Boechari, 1958, Tembaga Tulis Polengan. Skripsi Sarjana FSUI.

Boechari, 1977a, Manfaat Studi Bahasa Dan Sastra Jawa Kuna Ditinjau Dari Segi Sejarah Dan Arkeologi, Majalah Arkeologi. Th.I. No. I. September 1977. Hal. 5-30.

Boechari, 1977b, Epigrafi Dan Sejarah Indonesia, Majalah Arkeologi. Th.2. No. 2. November 1977. Hal. 1--35.

Boechari, 1980, Candi Dan lingkungannya, dalam Pertemuan Jlmiah Arkeologi. Cibulan, 21-25 Februari 1977. Jakarta: Pusat Penelitian Purbakala dan Peninggalan Nasional. Hal. 342-357.

Budhisantoso, 1982/1983, Ethnohistory Sebagai Pendekatan Sejarah Di Indonesia, Seminar Sejarah Nasional Indonesia 111:Panel Ethnohistori. Jakarta: Departemen Pendidikan dan Kebudayaan, Direktorat Sejarah dan Nilai Tradisional. Proyek Inventarisasi Dan Dokumentasi Sejarah Nasional. Hal. 22-25.

Claude Guillot, 1999, Orang Kalang: Juru Angkat Dan Pegadaian (Sub Terna Etnistas Dalam Pandangan Luar), dalam Henry Chambert-Loir dan Hasan Muarif Ambary (Ed.), Panggung Sejarah, Persembahan Kepada Prof. Dr. Denys Lombard. Jakarta: Ecole Francaise d'Extreme-Orient, Pusat Penelitian Arkeologi Nasional, Yayasan Obor Indonesia.

de Casparis J.G., 1956, Prasasti Indonesia (Sleeted Inscriptions From The 7th To The 9th Century A.D., Bandung: Masa baru.

de Casparis J.G., 1958, Short Inscriptions From Tjandi Plaosan Lor, Berita Dinas Purbakala:Bulletin of The Archaeological Service of The Republic Indonesia. No.4. Djakarta. 
Damais, Louis-Charles, 1970, Repertoire Onomastique DE L'Epigraphie Javaoaise (Jusqu'a $\mathrm{Pu}$ Sindok Sri Isanawikrama Dharmmotungadewa). Etude Epigraphie Indonesienne. Publications DE L'Ecole Francaise D'Extreme Orient. Volume LXI. Paris:DE L'Ecole Francaise D'Extreme Orient.

Ernst Cassirer, 1990, Manusia dan Kebudayaan (Sebuah Esei Tentang Manusia). Jakarta: Penerbit PT. Gramedia.

Franz Magnis-Suseno, 1985, Etika Jawa: Sebuah Analisa Falsafi Tentang Kebijaksanaan Hidup Jawa, Jakarta: Penerbit PT. Gramedia.

Harimurti Kridalaksana, 1990, Kelas Kata Dalam Bahasa Indonesia. Jakarta: Penerbit PT. Gramedia.

Hariani Santiko, 1982, Bhatari Durga, Disertasi. Jakarta: Fakultas Sastra Universitas Indonesia.

Haryati Soebadio, 1983, Tatabahasa Sanskerta Ringkas. Jakarta: Penerbit Djambatan.

Lelono, H. (1989). Upacara Kalang Obong (Suatu Tinjauan Etno-Arkeologi). Berkala Arkeologi, 10(1), 1-9. https://doi.org/10.30883/jba.v10i1.533

Juynboll, H.H, 1923, Oud-Javaansche-Nederlandsch Woodenlijst. Leiden E.J.Brill.

Kat, J ., dan Soeriadiradja, 1982, Tata Bahasa Dan Ungkapan Bahasa Sunda. Seri 1LDEP di bawah Redaksi W.A.L.Stokhof. Jakarta: Penerbit Djambatan.

LBSS, 1984, Kamus Umum Basa Sunda. Bandung: Penerbit Tarate.

Lien Dwiari Ratnawati, 1999, Penyajian Makanan Upacara Pada Masa Jawa Kuna: Kajian Prasasti dan Teks Sastra. Tesis S2 Arkeologi, Program Pascasarjana Universitas Indonesia.

Niels A. Mulder, 1973, Kepribadian Jawa dan Pembangunan Nasional. Yogyakarta: Gadjah Mada University Press.

Parsudi Suparlan ( editor), Manusia, Kebudayaan, Dan Lingkungannya. Jakarta: C.V. Rajawali Press. 
Parsudi Suparlan, 1977, Antropologi dan Pembangunan, dalam E.K.M.Maninambow (Ed.), Koentjaraningrat Dan Antropologi Di Indonesia. Jakarta: Diterbitkan oleh Asosiasi Indonesia Bekerjasama dengan Yayasan Obor Indonesia. Hal. 61-67.

Robins R.H., 1983, Sistem dan Struktur Bahasa Sunda, Seri ILDEP di bawah Redaksi W.A.L.Stokhof. Jakarta: Penerbit Djambatan.

Soekarto Kartoatmodjo, 1960, Topeng Sanghyang Puspasarira, Majalab Sana Budaya Tahun 1, No. 9. Desember 1960. Yogyakarta: Jawatan P dan K, Daerah istimewa Yogyakarta.

Soekarto Kartoatmodjo, 1985, Data Perundagian Di Dalam Prasasti Kuno, makalah disajikan dalam Diskusi llmiah Arkeologi. IAAI Komisariat Yogyakarta- dan Jawa Tengah Yogyakarta, Yogyakarta, 3-5 Juli 1985.

Stephanus Dajawanai, 1982/ 1983, Pengkajian Teles Lisan Sebagai Sumber Sejarah, makalah yang disajikan dalam Seminar Sejarab Nasional III (Panel Etnohistory). Departemen Pendidikan dan Kebudayaan: Direktorat Sejarah dan Nilai Tradisional. Proyek Inventarisasi dan Dokumentasi Sejarah Nasional. Hal. 1-21.

Suhendra Yusuf, 1998, Fonetik dan Fonologi, Jakarta: Penerbit PT. Gramedia Pustaka Utama.

Tome Pires, 1944, Suma Oriental, Hakluyt Society, 2nd series. LXXXIX. London. Terjemahan di dalam Sartono Kartodirdjo (editor), Masyarakat Kuno \& KelompokKelompok Sosial. Jakarta: Bhatara Karya Aksara. 1977. Hal. 43-70.

Verhaar, J.W.M. 1996, Azaz-azaz Linguistik Umumu (kerjasama Fr. B. Alip dkk.,). Gadjah Mada University Press.

Zando Zakaria, 1994, Rutan Dan Kesejaliteraan Masyarakat. Jakarta: Diterbitkan oleh Wahana Lingkungan Hidup Indonesia (WALHI). 